\title{
Efficacy of afoxolaner in the flea control in experimentally infested cats
}

\author{
Eficácia do afoxolaner no controle de pulgas em gatos experimentalmente infestados \\ Marília Alves Machado ${ }^{1 *}$ (D); Diefrey Ribeiro Campos²; Natália Lôres Lopes ${ }^{1}$; Isabela Pessôa Barbieri Bastos ${ }^{3}$; \\ Mariana Silva Revoredo Alves ${ }^{2}$; Thais Ribeiro Correia ${ }^{4}$; Fabio Barbour Scott ${ }^{4}$; Julio Israel Fernandes ${ }^{5}$

\begin{abstract}
${ }^{1}$ Programa de Pós-graduaçáo em Medicina Veterinária, Universidade Federal Rural do Rio de Janeiro - UFRRJ, Seropédica, RJ, Brasil
${ }^{2}$ Programa de Pós-graduação em Ciências Veterinárias, Universidade Federal Rural do Rio de Janeiro - UFRRJ, Seropédica, RJ, Brasil

${ }^{3}$ Faculdade de Medicina Veterinária, Universidade Federal Rural do Rio de Janeiro - UFRRJ, Seropédica, RJ, Brasil

${ }^{4}$ Departamento de Parasitologia Animal, Universidade Federal Rural do Rio de Janeiro - UFRRJ, Seropédica, RJ, Brasil
\end{abstract} \\ ${ }^{5}$ Departamento de Medicina e Cirurgia Veterinária, Universidade Federal Rural do Rio de Janeiro - UFRRJ, Seropédica, RJ, Brasil
}

Received March 27, 2019

Accepted July 19, 2019

\begin{abstract}
The aim of this study was to evaluate the efficacy of a single dose of oral afoxolaner in controlling fleas in cats. Fourteen cats were used. The cats were given identification numbers, housed individually, artificially infested with Ctenocephalides felis felis, and treated (or not) with afoxolaner. Were divided into a treatment group and a control group ( $\mathrm{n}=7 / \mathrm{group}$ ), on the basis of the fleas count hours after an infestation applied on Day (one-by-one allocation after ordering by count). At the start of the experimental protocol (designated day 0), the treated group received afoxolaner in a single dose of $2.5 \mathrm{mg} / \mathrm{kg}$ and the control group animals received a placebo. All animals were infested with $100 \mathrm{C}$. felis felis fleas two days before day 0 , as well as on days $5,12,19,26,33,40,47,54$, and 63 , parasite loads being evaluated at $48 \mathrm{~h}$ after each infestation. The efficacy of afoxolaner was $100 \%$ on day 2 and remained above $98 \%$ until day 42 , decreasing to $95.3 \%$ by day 63 . The findings confirm that a single dose of oral afoxolaner was effective in controlling C. felis felis in cats, and there were no observed adverse events.
\end{abstract}

Keywords: Dermatopathies, Ctenocephalides felis felis, treatment.

\section{Resumo}

O objetivo do estudo foi avaliar a eficácia de uma dose única de afoxolaner oral no controle de pulgas em gatos. Foram utilizados 14 gatos. Os animais foram identificados, alojados individualmente, infestados artificialmente com C. felis felis e tratados (ou não) com afoxolaner. Foram divididos em um grupo de tratamento e um grupo controle ( $\mathrm{n}=7 /$ grupo), com base na contagem de pulgas, horas após a infestação aplicada no dia (alocação de um por um após o período por contagem). No início do protocolo experimental (dia 0), o grupo tratado recebeu afoxolaner em dose inicial de $2,5 \mathrm{mg} / \mathrm{kg}$ e os animais do grupo controle receberam um placebo. Todos os animais foram infestados com 100 pulgas $C$. felis felis dois dias antes do dia 0 , assim como nos dias 5, 12, 19, 26, 33, 40, 47, 54 e 63, sendo avaliadas as cargas parasitárias às $48 \mathrm{~h}$ após cada infestaçáo. A eficácia do afoxolaner foi de $100 \%$ no dia 2 e permaneceu acima de $98 \%$ até o dia 42 , diminuindo para $95,3 \%$ no dia 63 . Os resultados confirmam que uma dose única de afoxolaner oral foi eficaz no controle de $C$. felis felis em gatos, e não houve eventos adversos observados.

Palavras-chave: Dermatopatias, Ctenocephalides felis felis, tratamento.

\section{Introduction}

Fleas Ctenocephalides felis felis are the most common parasite of dogs and cats (RUST \& DRYDEN, 1997). Because of the hematophagous characteristics of $C$. felis felis, this parasite ism can cause damage to animal health, resulting in common anemic

*Corresponding author: Marília Alves Machado. Universidade Federal Rural do Rio de Janeiro - UFRRJ, BR 465, Km 07, CEP 23897-000, Seropédica, RJ, Brasil. e-mail: ninaalvesvet@gmail.com conditions and flea allergy dermatitis (KRAMER \& MENCKE, 2001). Fleas transmit the feline leukemia virus and feline calicivirus (VOBIS et al., 2003; HARTMANN, 2006; MENCKE et al., 2009). Cat fleas have also been shown to be intermediate hosts of pathogens such as Rickettsia spp., Bartonella henselae, Dipylidium caninum, and Acanthocheilonema reconditum (BOUHSIRA et al., 2015; CHANDRA et al., 2017). 
Drugs belonging to the isoxazoline group are the newest ectoparasiticides available on the market (BEUGNET et al., 2015). Among them, fluralaner, when given orally off label, has been shown to be effective in the treatment of demodectic mange, as well as infestation with the cat fur mite Lynxacarus radovskyi, in cats, and topical application of the selamectin-sarolaner combination has proven safe and effective for use in cats (HAN et al., 2016; BECSKEI et al., 2017a; DUANGKAEW \& HOFFMAN, 2018).

A new member of the isoxazoline group, afoxolaner, acts as acaricide and insecticide, promoting elimination in dogs when administered at an oral dose of $2.5 \mathrm{mg} / \mathrm{kg}$ (BEUGNET et al., 2016). It binds to gamma-aminobutyric acid-gated chloride receptors and arachnid L-glutamate chloride channels, resulting in the death of parasites (BEUGNET et al., 2015). Although there have been reports of the isolated use of afoxolaner, described as a species-safe molecule, in dogs (LETENDRE et al., 2014), its use in cats has been restricted to the control of the Otodectes cynotis mite (MACHADO et al., 2018) and further studies are needed. Therefore, the aim of this study was to evaluate the parasiticidal efficacy and clinical safety of afoxolaner in cats infested with $C$. felis felis.

\section{Materials and Methods}

The study was approved by the Ethics in Animal Care and Use Committee of the Federal Rural University of Rio de Janeiro (Reference no. 6041210417) and was conducted in compliance with good standards of animal husbandry, according to the criteria established in the International Society of Feline Medicine Feline-Friendly Handling Guidelines (RODAN et al., 2011). To evaluate efficacy, we followed the guidelines of the World Association for the Advancement of Veterinary Parasitology (MARCHIONDO et al., 2013).

\section{Animals and ectoparasites}

Fourteen cats, including both males and females, weighing 2.6-4.7 kg, between two and six years of age, were obtained from the Laboratory of Experimental Chemotherapy in Veterinary Parasitology for use in this study. Prior to the commencement of the study, the animals were evaluated separately, in terms of clinical parameters (e.g., appearance of the mucosa, heart rate, respiratory rate, and capillary refill time), biochemical parameters, and eligibility. Thereafter, they were allocated to individual cages measuring approximately $2 \mathrm{~m}^{2}$, given ad libitum access to tap water and fed a commercial diet twice a day. In the 60 days prior to the experiment, none of the animals had received any medications for flea control. The fleas used in this study were obtained from experimental colonies maintained in the Laboratory of Experimental Chemotherapy in Veterinary Parasitology.

\section{Experimental procedures}

This was a longitudinal, randomized, clinical negative control study designed to evaluate the efficacy of afoxolaner as a pulicide in cats. Two weeks prior to afoxolaner administration, the 14 animals selected were allocated to the cages for acclimatization. Were also evaluated in all cats: vomiting, diarrhea, anuria, sialorrhea, hydration, heart rate, respiratory rate, and capillary refill time. Cats showing any of those signs would not have been included in the study. Animals were allocated to receive afoxolaner or a placebo, thus constituting a treated group and a control group ( $n=7 /$ group), on the basis of the first flea count after artificial infestation (ordered by count and allocated one by one). At the beginning of the experimental protocol (i.e., on day 0 ), animals in the treated group received oral afoxolaner in a single dose of 2.5 mg/kg (NexGard; Merial Salud Animal Ltda., São Paulo, Brazil). For $4 \mathrm{~h}$ after the administration of the medication, the cats in both groups remained under observation by veterinarians, who also examined the animals on a daily basis until the end of the experiment, in order to identify any adverse reactions.

At one week before afoxolaner administration, the cats were combed multiple times, from the head to the tail, with a fine-toothed comb (approximately 13 teeth $/ \mathrm{cm}$ ), to ensure removal of any incidental fleas acquired from the environment. Two days before administration of the medication, as well as on days $5,12,19,26,33,40,47,54$, and 63, each animal was infested with 50 pairs of $C$. felis felis, applied to the cervical region. At $48 \mathrm{~h}$ after Day 0 , and each infestation (i.e., on days $2,7,14,21,28,35,42,49,56$, and 65), the animals were thoroughly flea combed and flea counts recorded.

\section{Statistical analysis}

Data were checked for normality with the Shapiro-Wilk test. Comparisons between the two groups were made with the Kruskal-Wallis test, followed by the Student-Newman-Keuls test. Values of $\mathrm{p} \leq 0.05$ were considered statistically significant (SAMPAIO, 1998). Statistical analyses were performed with the statistical software program BioEstat, version 5.3 (AYRES et al., 2007).

\section{Results}

All of the animals ingested the chewable tablet of afoxolaner and received the full dose or at last $2.5 \mathrm{mg} / \mathrm{kg}$. By $48 \mathrm{~h}$ after the administration of the drug, fleas were eliminated from the animals in the treated group, and this was also observed following the next 2 infestations, showing that afoxolaner was 100\% efficacious in controlling fleas in the first two weeks (Table 1). On day 21, two of the treated animals presented a single flea each, reducing the overall efficacy to $99.5 \%$. On day 35 , one of the treated cats presented two fleas, the efficacy therefore remaining the same $(99.5 \%)$. On day 42 , one of the treated cats presented five fleas, indicating an efficacy of $98.2 \%$. On days 56 and 63, respectively, one cat presented with 21 and 22 fleas, and two to three cats presented with 1-3 fleas, the efficacy thus decreasing to $94.3 \%$ and $95.3 \%$, respectively. Therefore, the overall efficacy of the drug ranged from $100 \%$ to $94.3 \%$ during the study period ( $\mathrm{p}=0.0017$ vs. placebo). 
Table 1. Counts of fleas of the subspecies Ctenocephalides felis felis recovered from cats during the experimental period, together with the means and standard deviations for each group, as well as the efficacy of oral afoxolaner, at a single dose of $2.5 \mathrm{mg} / \mathrm{kg}$, in the treated group.

\begin{tabular}{|c|c|c|c|c|c|c|c|c|c|c|c|}
\hline \multirow{2}{*}{$\begin{array}{l}\text { Group } \\
\text { Animal }\end{array}$} & \multicolumn{11}{|c|}{ Day* } \\
\hline & -2 & 2 & 7 & 14 & 21 & 28 & 35 & 42 & 49 & 56 & 63 \\
\hline \multicolumn{12}{|l|}{ Control } \\
\hline 1 & 43 & 27 & 37 & 47 & 59 & 47 & 84 & 87 & 66 & 77 & 61 \\
\hline 2 & 29 & 28 & 26 & 20 & 47 & 42 & 33 & 41 & 36 & 59 & 68 \\
\hline 3 & 27 & 30 & 27 & 33 & 44 & 48 & 52 & 47 & 108 & 61 & 102 \\
\hline 4 & 24 & 21 & 28 & 32 & 32 & 33 & 21 & 23 & 38 & 51 & 55 \\
\hline 5 & 42 & 22 & 27 & 34 & 77 & 51 & 49 & 69 & 64 & 82 & 74 \\
\hline 6 & 29 & 30 & 43 & 30 & 79 & 59 & 73 & 69 & 55 & 82 & 75 \\
\hline 7 & 27 & 41 & 43 & 14 & 46 & 36 & 57 & 56 & 46 & 65 & 79 \\
\hline Mean & 31.6 & 28.4 & 33.0 & 30.0 & 54.9 & 45.1 & 52.7 & 56.0 & 59.0 & 68.1 & 73.4 \\
\hline SD & 7.7 & 6.6 & 7.8 & 10.6 & 17.7 & 8.9 & 21.7 & 21.2 & 24.6 & 12.3 & 15.1 \\
\hline \multicolumn{12}{|l|}{ Treated } \\
\hline 8 & 32 & 0 & 0 & 0 & 1 & 0 & 2 & 5 & 10 & 22 & 21 \\
\hline 9 & 32 & 0 & 0 & 0 & 0 & 0 & 0 & 0 & 1 & 2 & 1 \\
\hline 10 & 26 & 0 & 0 & 0 & 0 & 1 & 0 & 2 & 0 & 0 & 0 \\
\hline 11 & 24 & 0 & 0 & 0 & 0 & 0 & 0 & 0 & 0 & 0 & 0 \\
\hline 12 & 38 & 0 & 0 & 0 & 1 & 1 & 0 & 0 & 1 & 0 & 1 \\
\hline 13 & 31 & 0 & 0 & 0 & 0 & 0 & 0 & 0 & 6 & 0 & 0 \\
\hline 14 & 21 & 0 & 0 & 0 & 0 & 0 & 0 & 0 & 9 & 3 & 1 \\
\hline Mean & 29.1 & 0.0 & 0.0 & 0.0 & 0.3 & 0.3 & 0.3 & 1.0 & 3.9 & 3.9 & 3.9 \\
\hline SD & 5.8 & $\mathbf{0}$ & $\mathbf{0}$ & $\mathbf{0}$ & 0.5 & 0.5 & 0.8 & 1.9 & 4.4 & 8.1 & 7.8 \\
\hline Efficacy (\%) & - & 100 & 100 & 100 & 99.5 & 99.4 & 99.5 & 98.2 & 93.5 & 94.3 & 95.3 \\
\hline p-value & - & 0.0017 & 0.0017 & 0.0017 & 0.0017 & 0.0017 & 0.0017 & 0.0017 & 0.0017 & 0.0017 & $\mathbf{0 . 0 0 1 7}$ \\
\hline
\end{tabular}

*The day on which afoxolaner (or the placebo) was administered was designated day 0 .

\section{Discussion}

Within the isoxazoline class of drugs, the formulations approved for use in felines are sarolaner and fluralaner. Sarolaner was described by Becskei et al. (2017a) in a spot-on formulation, and no adverse clinical events were observed. In addition, Walther et al. (2016) described fluralaner for spot-on administration in cats as a safe formulation, allowing pharmacological associations to be made without the risk of clinical changes. Taenzler et al. (2017) also reported that spot-on administration of a fluralaner-based formulation in cats provoked no adverse effects. In the present study, with afoxolaner no adverse effects being observed in any of the animals treated.

That afoxolaner has prolonged efficacy in cats, eliminating parasites by $48 \mathrm{~h}$ after administration, as was described in dogs by Letendre et al. (2014). This is also in agreement with the findings of Six et al. (2016), who reported an average elimination of $99.8 \%$ of ectoparasites within $24 \mathrm{~h}$.

Drugs that act soon after administration are important for the control of infestations and serve as useful tools in the treatment of diseases triggered by hypersensitivity to flea bites, although long-term effects are also necessary in order to prevent new infestations and control the transmission of pathogens (BOUHSIRA et al., 2015; CHANDRA et al., 2017). Most insecticidal drugs recommended for dogs and cats have an average protection duration of 30 days. In the present study, a single dose of afoxolaner provided an efficacy ranging from $100 \%$ to $95 \%$ over a period of 63 days, thus avoiding future reinfestations by fleas (SIX et al., 2016). This corroborates the findings of Hunter et al. (2014), who showed that afoxolaner was $100 \%$ efficacious in controlling fleas for 21 days after administration, thus preventing the commencement of a new cycle of parasites, in dogs.

Other authors have demonstrated the efficacy of sarolaner for the control of ectoparasites in cats (BECSKEI et al., 2017b). Sarolaner has also been reported to be efficacious as a topical therapy for the treatment of otoacariasis, with efficacy similar to that of oral afoxolaner (MACHADO et al., 2018).

\section{Conclusion}

At a single oral dose of $2.5 \mathrm{mg} / \mathrm{kg}$, afoxolaner appears to be effective in controlling $C$. felis felis in cats for up to two months. Afoxolaner also appears to be safe, provoking no adverse clinical reactions.

\section{References}

Ayres M, Ayres M Jr, Ayres DL, Santos AAS. Bioestat 5.0 aplicaçôes estatísticas nas áreas das ciências biológicas e médicas. Belém: Sociedad Civil Mamirauá; 2007. p. 364.

Becskei C, Cherni JA, Vatta AF, King VL, Lin D, Rugg D. Efficacy and speed of kill of a new spot-on formulation of selamectin plus sarolaner 
against flea infestations in cats. Vet Parasitol 2017a; 238(Suppl. 1): S18-S21. http://dx.doi.org/10.1016/j.vetpar.2017.03.010.

Becskei C, Reinemeyer C, King VL, Lin D, Myers MR, Vatta AF. Efficacy of a new spot-on formulation of selamectin plus sarolaner in the treatment of Otodectes cynotis in cats. Vet Parasitol 2017b; 238(Suppl. 1): S27-S30. http://dx.doi.org/10.1016/j.vetpar.2017.02.029. PMid:28395753.

Beugnet F, Liebenberg J, Halos L. Comparative speed of efficacy against Ctenocephalides felis of two oral treatments for dogs containing either afoxolaner or fluralaner. Vet Parasitol 2015; 207(3-4): 297-301. http:// dx.doi.org/10.1016/j.vetpar.2014.12.007. PMid:25564276.

Beugnet F, Vos C, Liebenberg J, Halos L, Larsen D, Fourie J. Efficacy of afoxolaner in a clinical field study in dogs naturally infested with Sarcoptes scabiei. Parasite 2016; 23(26):1-15 http://dx.doi.org/10.1051/ parasite/2016026. PMid:27317462.

Bouhsira E, Franc M, Lienard E, Bouillin C, Gandoin C, Geurden T, et al. The efficacy of a selamectin (Stronghold ${ }^{\oplus}$ ) spot on treatment in the prevention of Bartonella henselae transmission by Ctenocephalides felis in cats, using a new high-challenge model. Parasitol Res 2015; 114(3): 10451050. http://dx.doi.org/10.1007/s00436-014-4271-4. PMid:25582566.

Chandra S, Forsyth M, Lawrence AL, Emery D, Slapeta J. Cat fleas (Ctenocephalides felis) from cats and dogs in New Zealand: molecular characterisation, presence of Rickettsia felis and Bartonella clarridgeiae and comparison with Australia. Vet Parasitol 2017; 234: 25-30. http:// dx.doi.org/10.1016/j.vetpar.2016.12.017. PMid:28115179.

Duangkaew L, Hoffman H. Efficacy of oral fluralaner for the treatment of Demodex gatoi in two shelter cats. Vet Dermatol 2018; 29(3): 262. http://dx.doi.org/10.1111/vde.12520. PMid:29388292.

Han HS, Noli C, Cena T. Efficacy and duration of action of oral fluralaner and spot-on moxidectin/imidacloprid in cats infested with Lynxacarus radovskyi. Vet Dermatol2016; 27(6): 474-e127. http://dx.doi.org/10.1111/ vde.12390. PMid:27870235.

Hartmann K. Feline leukemia virus infection. In: Greene CE. Infectious diseases of the dog and cat. 3nd ed. St. Louis: Saunders Elsevier; 2006. p. $105-130$.

Hunter JS 3rd, Dumont P, Chester TS, Young DR, Fourie JJ, Larsen DL. Evaluation of the curative and preventive efficacy of a single oral administration of afoxolaner against cat flea Ctenocephalides felis infestations on dogs. Vet Parasitol 2014; 201(3-4): 207-211. http://dx.doi. org/10.1016/j.vetpar.2014.02.024. PMid:24629423.

Kramer F, Mencke N. Flea biology and control. Berlin: Springer; 2001. p. 192.

Letendre L, Huang R, Kvaternick V, Harriman J, Drag M, Soll M. The intravenous and oral pharmacokinetics of afoxolaner used as a monthly chewable antiparasitic for dogs. Vet Parasitol 2014; 201(3-4): 190-197. http://dx.doi.org/10.1016/j.vetpar.2014.02.021. PMid:24685320.

Machado MA, Campos DR, Lopes NL, Barbieri Bastos IP, Botelho CB, Correia TR, et al. Efficacy of afoxolaner in the treatment of otodectic mange in naturally infested cats. Vet Parasitol 2018; 256: 29-31. http:// dx.doi.org/10.1016/j.vetpar.2018.04.013. PMid:29887026.

Marchiondo AA, Holdsworth PA, Fourie LJ, Rugg D, Hellmann K, Snyder DE, et al. World Association for the Advancement of Veterinary Parasitology (W.A.A.V.P) second edition: Guidelines for evaluating the efficacy of parasiticides for the treatment, prevention and control of flea and tick infestations on dogs and cats. Vet Parasitol 2013; 194(1): 84-97. https://doi.org/10.1016/j.vetpar.2013.02.003

Mencke N, Vobis M, Mehlhorn H, D'Haese J, Rehagen M, MangoldGehring S, et al. Transmission of feline calicivirus via the cat flea (Ctenocephalides felis). Parasitol Res 2009; 105(1): 185-189. http://dx.doi. org/10.1007/s00436-009-1381-5. PMid:19277714.

Rodan I, Sundahl E, Carney H, Gagnon AC, Heath S, Landsberg G, et al. AAFP and ISFM Feline-Friendly handling guidelines. J Feline Med Surg 2011; 13(1): 364-375. http://dx.doi.org/10.1016/j.jfms.2011.03.012. PMid:21515223.

Rust MD, Dryden MK. The biology, ecology, and management of the cat flea. Annu Rev Entomol 1997; 42(1): 451-473. http://dx.doi.org/10.1146/ annurev.ento.42.1.451. PMid:9017899.

Sampaio IBM. Estatística aplicada à experimentação animal. Belo Horizonte: Fundação de Ensino e Pesquisa em Medicina Veterinária e Zootecnia; 1998. p. 265.

Six RH, Liebenberg J, Hosberger NA, Mahabir SP. Comparative speed of kill of sarolaner $\left(\right.$ Simparica $\left.^{\mathrm{TM}}\right)$ and afoxolaner $\left(\mathrm{NexGard}{ }^{\circledR}\right)$ against induced infestations of Ctenocephalides felis on dogs. Parasit Vectors 2016; 9(1): 1-13. http://dx.doi.org/10.1186/s13071-016-1372-1. PMid:26896428.

Taenzler J, Vos C, Roepke RKA, Frénais R, Heckeroth AR. Efficacy of fluralaner against Otodectes cynotis infestations in dogs and cats. Parasit Vectors 2017; 10(30): 1-14. http://dx.doi.org/10.1186/s13071-0161954-y. PMid:28093080.

Vobis M, D’Haese J, Mehlhorn H, Mencke N. Evidence of horizontal transmission of feline leukemia virus by the cat flea (Ctenocephalides felis). Parasitol Res 2003; 91(6): 467-470. http://dx.doi.org/10.1007/ s00436-003-0949-8. PMid:14557874.

Walther FM, Allan MJ, Roepke RKA. Safety of concurrent treatment of cats with fluralaner and emodepsid-praziquantel. Parasit Vectors 2016; 9(1): 1-7. http://dx.doi.org/10.1186/s13071-016-1618-y. PMid:27267592. 